\title{
(2) OPEN ACCESS \\ Accident prevention activity and accident experience in the Republic of Korea military
}

\author{
Hwi Jun Kim $\odot$, , ${ }^{1}$ S Y Oh, ${ }^{1}$ D W Choi, ${ }^{1}$ S Y Won, ${ }^{2}$ H J Kim, ${ }^{3}$ S C Ko, ${ }^{4}$ S Y Woo, ${ }^{5}$ \\ E-C Park ${ }^{6}$
}

'Department of Public Health, Institute of Health Services Research, Yonsei University, Seodaemun-gu, Korea (the Republic of)

${ }^{2}$ Department of Medical Logistics, Army Logistics Command, Daejeon, Korea (the Republic of)

${ }^{3}$ Department of Medical, Second Operational Command, Daegu, Korea (the Republic of)

${ }^{4}$ Armed Forces Medical School, Daejeon, Korea (the Republic of) ${ }^{5}$ Department of Nurse, Yonsei University, Seodaemun-gu, Korea (the Republic of) ${ }^{6}$ Department of Preventive Medicine and Institute of Health Services Research, Yonsei University, Seodaemun-gu, Korea (the Republic of)

\section{Correspondence to}

Professor E-C Park, Department of Preventive Medicine \& Institute of Health Services Research, Yonsei University, Seodaemun-gu 03722, Korea (the Republic of); ecpark@ yuhs.ac

Received 9 July 2019

Revised 16 September 2019 Accepted 20 September 2019

Check for updates

(c) Author(s) (or their employer(s)) 2020. Re-use permitted under CC BY-NC. No commercial re-use. See rights and permissions. Published by BMJ.

To cite: Kim HJ, Oh SY, Choi DW, et al. BMJ Military Epub ahead of print: [please include Day Month Year]. doi:10.1136/

jramc-2019-001279

\section{ABSTRACT}

Introduction According to data released by the Korea National Statistical Office, the number of accidents has been decreasing since 2012. However, a considerable number of deaths related to safety accidents (23-46 deaths) are still reported annually. This study aimed to observe the correlation between accident prevention activities in the Republic of Korea (ROK) military and the incidence of safety accidents.

Methods The study used data from the 2014-2015 Military Health Survey and included 13618 responses (Army: 8414 (61.8\%); Navy/Marine: 2262 (16.6\%); Air Force: $2942(21.6 \%))$ from the ROK military personnel. Accident experiences and thoughts on accident prevention activities were self-reported. Multiple logistic regression analysis was used to examine the validity of accident prevention activity and accident experience.

Results Of the 13618 military personnel who responded, $12.0 \%$ reported experiencing safety accidents in the military and $1020(7.5 \%)$ felt that accident prevention activities in the military were insufficient. On logistic regression analysis, we found a significant difference (insufficiency $\mathrm{OR}=1.56, \mathrm{Cl} 1.31$ to 1.86). In particular, military personnel who belong to the Army and Navy were more likely to think that accident prevention activities were insufficient. In addition, military personnel who experienced falls/slips, crash, and laceration/puncture wound/amputation/penetrating wound accidents were more likely to think accident prevention activities were insufficient.

Conclusions Our study found that accident prevention activities in the military and accident experiences were related. It is necessary for the ROK Ministry of Defense, Army, Navy and Air Force headquarters to re-evaluate their accident prevention systems.

\section{INTRODUCTION}

Military personnel can face serious injuries and even fatal injuries, ${ }^{1-3}$ and such accidents, which cause non-combat losses, are factors causing difficulties in maintaining military combat power. ${ }^{4-6}$ Furthermore, in the event of an accidental death, the incident itself may affect the morale of the armed forces or may result in the nation losing confidence in or withdrawing support from the military.

Some safety accidents can be expected or are predictable. However, due to the unexpected nature of the majority of safety accidents, they are generally difficult to predict. Such accidents can be prevented by identifying and modifying risk factors or possibilities of accidents, ${ }^{8-11}$ accident prevention activity (education and safety inspections), and continuous efforts to prevent such incidents. ${ }^{12-14}$

\section{Key messages}

- This study confirmed the association between military accident prevention activities and the safety accident experience.

- It is necessary re-check each military's accident prevention system.

However, despite efforts to prevent accidents, safety accidents in the armed forces continue to occur, prompting us to ask whether the military's accident prevention activity is sufficient.

According to data released by the Korea National Statistical Office, 46 military personnel died due to safety accidents in 2010. The number of accidents has been decreasing since 2012. However, a considerable number of deaths related to safety accidents (23-46 deaths) are still reported annually, ${ }^{15}$ although these data only report the number of deaths and not the number of non-fatal safety accidents that occur in an individual's military life. Based on these data, we investigated whether there was any correlation between accident experience in the military and accident prevention activity.

\section{METHODS}

Study participants

Data for our study population were obtained from the 2014-2015 Military Health Survey (MHS), a cross-sectional, military sample survey conducted by the School of Military Medicine designed to obtain military health determinants. This survey was based on a self-report questionnaire. The MHS was developed based on the Korea National Health and Nutrition Examination Survey (KNHANES) and was designed to determine the health status of the Republic of Korea (ROK) military personnel. The KNHANES is an ongoing surveillance system in the ROK that assesses the health and nutritional status of Koreans, monitors trends in health risk factors and the prevalence of major chronic diseases, and provides data for the development and evaluation of health policies and programmes in Korea. ${ }^{16}$ Similarly, the MHS collects data on military personnel's general characteristics, health behaviours, injuries, safety consciousness, social support, disease and medical service use, as well as characteristics that only apply to female military personnel. To represent the entire population of the ROK military personnel, the MHS uses stratified random sampling. Specifically, MHS sampling considers military personnel's sex, rank, service type and 
working area. Raw data were obtained from the Korean Military Medical School with the dean's approval. Since the 2014 MHS is an anonymous, self-administered survey, individual responses cannot be linked to specific personnel or medical records. A total of 14244 survey participants provided data during the two years of the study (officers and warrant officers: 1914; noncommissioned officers (NCOs): 3604; enlisted soldiers: 8726). We identified respondents who had responded to the following two items: accident experience during the past year and accident prevention activity $(n=14164)$. We excluded participants who did not respond to questions on sex $(n=10)$, educational level $(n=142)$, branch $(n=28)$, rank $(n=150)$, service classification $(n=88)$ and smoking $(n=128)$. Finally, data from 13618 personnel (officers and warrant officers: 1812; NCOs: 3406; enlisted soldiers: 8400) were obtained and analysed as a representative sample.

\section{Variables}

The main dependent variable in this study was accident experience in the previous one year, marked as either 'yes' or 'no' in the MHS. We conducted the study after excluding missing data on accident experience from our study population. The variable of interest was accident prevention activity, which we investigated through the MHS by asking 'Is there sufficient education and efforts to prevent accidents within the unit?' with the following possible answers: 'definitely yes', 'mostly', 'neutral', 'mostly not' and 'not at all'. We classified participants who responded

Table 1 General characteristics of the study (Military Health Survey 2014-2015)

\begin{tabular}{|c|c|c|c|c|c|c|c|}
\hline \multirow[b]{3}{*}{ Variable } & \multicolumn{6}{|c|}{ Experience of accident } & \multirow[b]{3}{*}{$P$ value } \\
\hline & \multicolumn{2}{|l|}{ Total } & \multicolumn{2}{|l|}{ Yes } & \multicolumn{2}{|l|}{ No } & \\
\hline & $\mathrm{n}$ & $\%$ & n & $\%$ & $\mathrm{n}$ & $\%$ & \\
\hline Accident prevention activity & & & & & & & $<0.0001$ \\
\hline Sufficient & 8184 & 60.1 & 860 & 10.5 & 7324 & 89.5 & \\
\hline Neutral & 4414 & 32.4 & 582 & 13.2 & 3832 & 86.8 & \\
\hline Insufficient & 1020 & 7.5 & 194 & 19 & 826 & 81 & \\
\hline Sex & & & & & & & 0.0002 \\
\hline Male & 13224 & 97.1 & 1612 & 12.2 & 11612 & 87.8 & \\
\hline Female & 394 & 2.9 & 24 & 6.1 & 370 & 93.9 & \\
\hline Marital status & & & & & & & $<0.0001$ \\
\hline Married & 1648 & 12.1 & 102 & 6.2 & 1546 & 93.8 & \\
\hline Once married (divorced, separated, bereaved) & 312 & 2.3 & 18 & 5.8 & 294 & 94.2 & \\
\hline Unmarried & 11658 & 85.6 & 1516 & 13 & 10142 & 87 & \\
\hline Educational level & & & & & & & 0.2982 \\
\hline High school or lower & 2508 & 18.4 & 286 & 11.4 & 2222 & 88.6 & \\
\hline College or higher & 11110 & 81.6 & 1350 & 12.2 & 9760 & 87.9 & \\
\hline Military type & & & & & & & $<0.0001$ \\
\hline Army & 8414 & 61.8 & 1120 & 13.3 & 7294 & 86.7 & \\
\hline Navy/Marine & 2262 & 16.6 & 242 & 10.7 & 2020 & 89.3 & \\
\hline Air Force & 2942 & 21.6 & 274 & 9.3 & 2668 & 90.7 & \\
\hline Branch & & & & & & & 0.2282 \\
\hline Combat & 8808 & 64.7 & 1080 & 12.3 & 7728 & 87.7 & \\
\hline Non-combat & 4810 & 35.3 & 556 & 11.6 & 4254 & 88.4 & \\
\hline Rank & & & & & & & $<0.0001$ \\
\hline Warrant officer and commissioned officer (W1-06) & 1812 & 13.3 & 74 & 4.1 & 1738 & 95.9 & \\
\hline Non-commissioned officer (E5-E9) & 3406 & 25 & 214 & 6.3 & 3192 & 93.7 & \\
\hline Enlisted soldier (E3-E4) & 4008 & 29.4 & 714 & 17.8 & 3294 & 82.2 & \\
\hline Enlisted soldier (E1-E2) & 4392 & 32.3 & 634 & 14.4 & 3758 & 85.6 & \\
\hline Working area & & & & & & & $<0.0001$ \\
\hline Forward area & 9014 & 66.2 & 1192 & 13.2 & 7822 & 86.8 & \\
\hline Rear area & 4604 & 33.8 & 444 & 9.6 & 4160 & 90.4 & \\
\hline Service classification & & & & & & & $<0.0001$ \\
\hline Long-term military service & 2950 & 21.7 & 160 & 5.4 & 2790 & 94.6 & \\
\hline Short-term military service & 10668 & 78.3 & 1476 & 13.8 & 9192 & 86.2 & \\
\hline Working type & & & & & & & 0.2284 \\
\hline Day work & 6752 & 49.6 & 834 & 12.4 & 5918 & 87.7 & \\
\hline Shift work & 6866 & 50.4 & 802 & 11.7 & 6064 & 88.3 & \\
\hline Smoking & & & & & & & $<0.0001$ \\
\hline Current smoker & 5966 & 43.8 & 608 & 10.2 & 5358 & 89.8 & \\
\hline Former smoker & 848 & 6.2 & 120 & 14.2 & 728 & 85.9 & \\
\hline Non-smoker & 6804 & 50 & 908 & 13.4 & 5896 & 86.7 & \\
\hline Total & 13618 & 100 & 1636 & 12 & 11982 & 88 & \\
\hline
\end{tabular}


'definitely yes' or 'mostly' as the group who felt that accident prevention education and efforts were sufficient. People who responded with 'neutral' were classified as the neutral group. The remaining respondents were classified as the group that considers accident prevention education and efforts to be insufficient. Several covariates were also assessed, including sociodemographic, military-related and health-related characteristics. Sociodemographic characteristics included sex (male, female), marital status (married, once married (divorced, separated, bereaved), unmarried) and educational level (high school or lower, college or higher). Military-related characteristics included military type (Army, Navy/Marine, Air Force), branch (combat, technique/administration, special), rank (warrant officer and commissioned officer (W1-O6), NCO (E5-E9), enlisted soldier (E3-E4), enlisted soldier (E1-E2)), working area (forward, rear), service classification (long-term military service, short-term military service), working type (day work, shift work) and smoking (current smoker, former smoker, non-smoker).

\section{Statistical analysis}

$\chi^{2}$ test and logistic regression analysis were used to analyse the association between accident prevention activity and accident experience. $\chi^{2}$ test was used to examine significant differences in accident experience, depending on the accident prevention activity. Multiple logistic regression analysis was used to determine OR and 95\% CI. Subgroup analysis was performed according to accident experience, accident prevention activity, sex, marital status, educational level, military type, branch, working area, service classification, working type and smoking. We conducted a subgroup analysis of dependent variables to analyse the perception of accident prevention activity according to the type of accident. Statistical analyses were performed using SAS V.9.4 software. Significance level was set at $\mathrm{p}<0.05$.

\section{RESULTS}

Our sample included 13618 military personnel (Army: 8414 (61.8\%); Navy/Marine: 2262 (16.6\%); Air Force: 2942 (21.6\%)). According to our analysis, military personnel generally thought there were enough military accident prevention activities. Out of a total of 13618 military personnel, 8184 (60.1\%) thought they had sufficient accident prevention activities in the military, 4414 (32.4\%) were found to be neutral, and $1020(7.5 \%)$ thought accident prevention activities were insufficient (Table 1).

Table 2 shows the correlation between accident experience and accident prevention activity through multiple logistic regression analysis. Compared with the group who thought accident prevention activities were sufficient, the groups who considered accident prevention activities to be neutral and insufficient were more likely to have experienced accidents (Table 2).

Table 3 shows the results of a subgroup analysis of sex, marital status, educational level, military type, branch, working area, service classification and working type. In terms of educational level, those who were educated below high school and had experienced an accident were more likely to think that accident prevention activities in the military were neutral or insufficient (Table 3). In terms of military type, Army and Navy personnel who had experienced accidents considered accident prevention activities to be insufficient (Table 3). Additionally, military personnel that belonged to a combat branch are more likely to consider accident prevention activities to be insufficient (Table 3).

Figure 1 shows the results of the dependent variable subgroup analysis. This figure shows the accident prevention activity
Table 2 Factors associated with experience of accident and accident prevention activity (Military Health Survey 2014-2015)

\begin{tabular}{|c|c|}
\hline & Experience of accident \\
\hline Variables & Adjusted OR $(95 \% \mathrm{Cl})$ \\
\hline \multicolumn{2}{|l|}{ Accident prevention activity } \\
\hline Sufficient & 1.00 \\
\hline Neutral & $1.12(0.99$ to 1.25$)$ \\
\hline Insufficient & $1.56(1.31$ to 1.86$)$ \\
\hline \multicolumn{2}{|l|}{ Sex } \\
\hline Male & 0.75 (0.48 to 1.16$)$ \\
\hline Female & 1.00 \\
\hline \multicolumn{2}{|l|}{ Marital status } \\
\hline Married & 1.00 \\
\hline Once married (divorced, separated, bereaved) & $0.96(0.57$ to 1.61$)$ \\
\hline Unmarried & $0.78(0.57$ to 1.07$)$ \\
\hline \multicolumn{2}{|l|}{ Educational level } \\
\hline High school or lower & 1.00 \\
\hline College or higher & $1.16(1.01$ to 1.33$)$ \\
\hline \multicolumn{2}{|l|}{ Military type } \\
\hline Army & 1.00 \\
\hline Navy/Marine & $1.02(0.85$ to 1.22$)$ \\
\hline Air Force & $0.92(0.76$ to 1.11$)$ \\
\hline \multicolumn{2}{|l|}{ Branch } \\
\hline Combat & 1.00 \\
\hline Non-combat & $1.06(0.94$ to 1.21$)$ \\
\hline \multicolumn{2}{|l|}{ Rank } \\
\hline Warrant officer and commissioned officer (W1-06) & 1.00 \\
\hline Non-commissioned officer (E5-E9) & 1.55 (1.17 to 2.05$)$ \\
\hline Enlisted soldier (E3-E4) & 4.87 (3.62 to 6.54$)$ \\
\hline Enlisted soldier (E1-E2) & 3.85 (2.86 to 5.18$)$ \\
\hline \multicolumn{2}{|l|}{ Working area } \\
\hline Forward area & 1.07 (0.92 to 1.25$)$ \\
\hline Rear area & 1.00 \\
\hline \multicolumn{2}{|l|}{ Service classification } \\
\hline Long-term military service & 1.00 \\
\hline Short-term military service & $1.20(0.89$ to 1.63$)$ \\
\hline \multicolumn{2}{|l|}{ Working type } \\
\hline Day work & $0.90(0.81$ to 1.01$)$ \\
\hline Shift work & 1.00 \\
\hline \multicolumn{2}{|l|}{ Smoking } \\
\hline Current smoker & 1.00 \\
\hline Former smoker & 1.43 (1.15 to 1.77$)$ \\
\hline Non-smoker & $1.40(1.25$ to 1.57$)$ \\
\hline
\end{tabular}

according to accident type. In most accident types, accident prevention activity was considered insufficient. In particular, military personnel who had suffered from falls/slips, crash, and laceration/puncture wound/amputation/penetrating wound were more likely to consider accident prevention activities to be insufficient, at a statistically significant level.

\section{DISCUSSION}

According to our research, the Korean government and the Ministry of National Defense need to revisit their safety education systems to ensure the safety of military personnel. First, the government needs to review the current safety management system. The system accounting for safety accidents is included in the Korean military policies. However, over the past decade, deaths caused by safety accidents in the military have been 
Table 3 Subgroup analysis of experience of accident and accident prevention activity by covariate

\begin{tabular}{|c|c|c|c|}
\hline \multirow[b]{3}{*}{ Variable } & \multicolumn{3}{|c|}{ Experience of accident } \\
\hline & Sufficient & Neutral & Insufficient \\
\hline & OR & OR $(95 \% \mathrm{Cl})$ & OR $(95 \% \mathrm{Cl})$ \\
\hline \multicolumn{4}{|l|}{ Sex } \\
\hline Male & 1.00 & 1.11 (0.99 to 1.25$)$ & 1.57 (1.32 to 1.88$)$ \\
\hline Female & 1.00 & $1.30(0.50$ to 3.40$)$ & $<0.001(<0.001$ to $>999.999)$ \\
\hline \multicolumn{4}{|l|}{ Marital status } \\
\hline Married & 1.00 & 0.90 (0.54 to 1.51$)$ & $0.90(0.54$ to 1.51$)$ \\
\hline Once married (divorced, separated, bereaved) & 1.00 & 0.21 (0.04 to 1.17$)$ & $<0.001 \quad(<0.001$ to $>999.999)$ \\
\hline Unmarried & 1.00 & 1.14 (1.01 to 1.29$)$ & $1.61(1.35$ to 1.93$)$ \\
\hline \multicolumn{4}{|l|}{ Educational level } \\
\hline High school or lower & 1.00 & 1.64 (1.25 to 2.16 & $2.20(1.46$ to 3.33$)$ \\
\hline College or higher & 1.00 & $1.02(0.90$ to 1.16$)$ & $1.46(1.20$ to 1.78$)$ \\
\hline \multicolumn{4}{|l|}{ Military type } \\
\hline Army & 1.00 & 1.07 (0.93 to 1.23$)$ & $1.62(1.31$ to 1.99$)$ \\
\hline Navy/Marine & 1.00 & 1.88 (1.39 to 2.53$)$ & 2.25 (1.36 to 3.73$)$ \\
\hline Air Force & 1.00 & 0.84 (0.64 to 1.12$)$ & 0.94 (0.59 to 1.50$)$ \\
\hline \multicolumn{4}{|l|}{ Branch } \\
\hline Combat & 1.00 & 1.09 (0.95 to 1.26$)$ & 1.75 (1.42 to 2.14$)$ \\
\hline Non-combat & 1.00 & 1.17 (0.96 to 1.42$)$ & 1.13 (0.79 to 1.61$)$ \\
\hline \multicolumn{4}{|l|}{ Working area } \\
\hline Forward area & 1.00 & 1.15 (1.01 to 1.32$)$ & 1.73 (1.42 to 2.12$)$ \\
\hline Rear area & 1.00 & 1.01 (0.81 to 1.27$)$ & $1.10(0.76$ to 1.60$)$ \\
\hline \multicolumn{4}{|l|}{ Service classification } \\
\hline Long-term military service & 1.00 & $0.74(0.491 .13)$ & 1.11 (0.52 to 2.36$)$ \\
\hline Short-term military service & 1.00 & 1.16 (1.03 to 1.31$)$ & 1.61 (1.34 to 1.93$)$ \\
\hline \multicolumn{4}{|l|}{ Working type } \\
\hline Day work & 1.00 & 0.97 (0.83 to 1.14$)$ & 1.44 (1.12 to 1.85$)$ \\
\hline Shift work & 1.00 & 1.29 (1.09 to 1.52$)$ & 1.70 (1.33 to 2.18$)$ \\
\hline \multicolumn{4}{|l|}{ Smoking } \\
\hline Current smoker & 1.00 & 1.12 (0.93 to 1.35$)$ & 1.68 (1.27 to 2.23$)$ \\
\hline Former smoker & 1.00 & 0.99 (0.65 to 1.52$)$ & 1.81 (0.094 to 3.48$)$ \\
\hline Non-smoker & 1.00 & 1.12 (0.96 to 1.31$)$ & 1.44 (1.13 to 1.84$)$ \\
\hline
\end{tabular}

approximately one-third of all annual deaths. ${ }^{15}$ This suggests Korean military policy reform. Second, preventive actions should be reinforced. Although there are numerous risk factors for safety accidents, some accidents could be prevented if the prevention activities are strengthened. An army is an organisation managed by schedules. In almost every mission, the personnel are warned

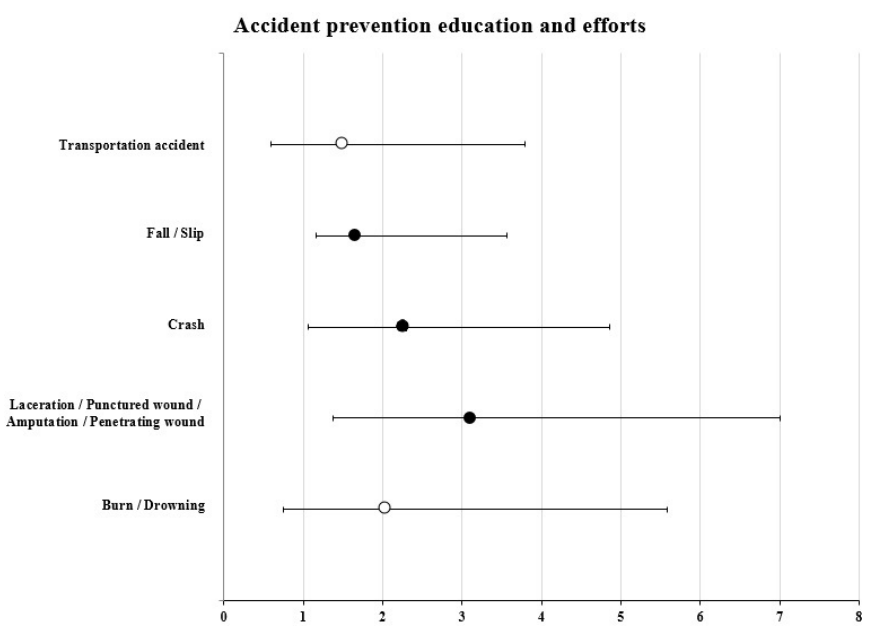

Figure 1 Accident prevention activity according to accident type. in advance and are aware of which mission they will be assigned to. If proper safety education and guidelines are provided prior to the next mission, fewer accidents are likely to occur. In addition, enhanced field monitoring conducted by administrations could play a role in contributing to fewer safety accidents. Third, it is necessary to train each unit's safety training specialist. To date, ROK military safety activities are mostly carried out by the officers of each unit. However, these officers are sometimes overloaded on duty as they are assigned multiple tasks aside from being in charge of safety activities. Also, some officers may not have expertise in the field, and therefore well-trained safety instructors are needed to deal exclusively with on-field monitoring. Fourth, the ongoing safety work in the military needs full review. Safety-related work is primarily managed by commissioned officers; however, they do not spend much time on the field. In most cases, they spend most of their time doing administrative work. On the other hand, it is usually the NCOs who are out on the field. Increased communication between commissioned and non-commissioned officers will enable commissioned officers to construct better plans that reflect NCOs' concerns with regard to on-field safety issues. Furthermore, if administrative work can be simplified, commissioned officers will be less occupied and will be able to spend more time out on the field with NCOs. 
Our research has some limitations. First, we asked whether or not soldiers had experienced accidents in the past year. However, the MHS used self-report questionnaires, thus recall bias may have occurred. Operation logs, which record and track accident history, could have been a more suitable source of data, but the military did not allow use of logs for security reasons. Second, this study is unable to explain the causal relationship between accident prevention activities and accidents in the military because this was conducted using a cross-sectional design. The findings of our study would have been more valid if we had used a longitudinal design, but this was not possible due to data limitations.

Our study identified trends between accident prevention activities and accident experiences in the military. This study suggests indepth review of current accident prevention activities to make up for deficiencies.

\section{CONCLUSION}

Our study found that accident prevention activities in the military and accident experiences were related. It is necessary for the ROK Ministry of Defense, Army, Navy and Air Force headquarters to re-evaluate their accident prevention systems.

Funding The authors have not declared a specific grant for this research from any funding agency in the public, commercial or not-for-profit sectors.

Disclaimer Any opinions or assertions expressed are solely those of the authors and do not necessarily represent those of the ROK Armed Forces, the Ministry of National Defense or the ROK Government.

Competing interests None declared.

Patient consent for publication Not required.

Ethics approval The institutional review board of the ROK AFMC provided formal ethics approval for the MHS data sets (IRB approval number AFMC-14-IRB-004, AFMC-15060-IRB-15-049).

Provenance and peer review Not commissioned; externally peer reviewed.
Data availability statement Data may be obtained from a third party and are not publicly available.

Open access This is an open access article distributed in accordance with the Creative Commons Attribution Non Commercial (CC BY-NC 4.0) license, which permits others to distribute, remix, adapt, build upon this work non-commercially, and license their derivative works on different terms, provided the original work is properly cited, appropriate credit is given, any changes made indicated, and the use is non-commercial. See: http://creativecommons.org/licenses/by-nc/4.0/.

\section{ORCID iD}

Hwi Jun Kim http://orcid.org/0000-0001-7007-8442

\section{REFERENCES}

1 Schuckit MA, Gunderson EK. Accident and assault deaths in the United States navy: demography and preliminary interpretations. Mil Med 1977;142:607-10.

2 Russell R. The approach to a major incident. J R Army Med Corps 2000;146:8-12.

3 Accidents and accidental injury. J R Army Med Corps 1968;114:2-4.

4 Dembert ML. Common sense strategies for accident and injury prevention. Mil Med $1990 ; 155: 20-2$

5 Malliarou M, Sourtzi P, Galanis P, et al. Occupational accidents in Greek armed forces in Evros County. J R Army Med Corps 2012;158:313-7.

6 McFarland RA, Moore RC. The prevention of accidents in the armed services. Mil Med 1963;128:1190-5.

7 Kang SY, Yoon SY, Han KS. The factors of SNS characteristics and organizational culture affecting military morale. Journal of Digital Convergence 2018;16:79-88.

$8 \mathrm{Kim}$ YJ. Research on military accidents: analysis of their nature analysis and prevention measures Chonnam National University; 2005.

9 Lund J, Aarø LE. Accident prevention. presentation of a model placing emphasis on human, structural and cultural factors. Saf Sci 2004;42:271-324.

10 Hoyos CG, Zimolong BM. Occupational safety and accident prevention: behavioral strategies and methods. Elsevier, 2014.

11 Suokas J. The role of safety analysis in accident prevention. Accid Anal Prev 1988;20:67-85.

12 The Ministry of administration and safety. National safety education promotion basic low. Korean law No.14839; 2017.

13 Pless IB. Accident prevention and health education: back to the drawing board? Pediatrics 1978;62:431-5.

14 King BG. Accident prevention research. Public Health Rep 1949;64:373-82.

15 Statistics Korea. R.O.K military death accident trend; 2018.

16 Kweon S, Kim Y, Jang M-jin, et al. Data resource profile: the Korea National health and nutrition examination survey (KNHANES). Int J Epidemiol 2014;43:69-77. 